\title{
The UK Foundation Programme for newly qualified doctors: a SWOT analysis
}

\author{
0 Foundation Programme do Reino Unido para médicos recém-formados: uma análise utilizando a \\ matriz DAFO
}

\section{El Foundation Programme del Reino Unido para los médicos recién titulados: un análisis utilizando la matriz DAFO}

David Stephen Lawrence. Brighton and Sussex University Hospitals NHS Trust. Brighton. United Kingdom. davidlawrence@doctors.org.uk (Corresponding author) Christopher Gareth Williams. Brighton and Sussex University Hospitals NHS Trust. Brighton. United Kingdom. cgwilliams@doctors.org.uk

\begin{abstract}
Introduction: After completing a five year undergraduate degree, all newly qualified doctors in the United Kingdom undertake a two-year Foundation Programme which aims to provide them with the necessary experience, supervision and guidance to prepare them for a career in clinical medicine. Foundation Doctors are paid members of the team and undertake a variety of clinical rotations with supervision from senior colleagues, a process that is regulated by a UK Foundation Programme Office. Objective: This paper aims to provide a reflective analysis of this programme to greater inform the international audience. Methods: A critical reflective analysis utilising the SWOT format (Strength, Weaknesses, Opportunities and Threats), conducted by two Foundation Doctors working in the UK. Results and Discussion: We identified a well-established programme which enabled graduates to gain a broad range of clinical experience as a paid doctor but one with considerable variation at both individual and group level. Long-standing shortcomings of being a junior-doctor including long hours and excessive paperwork were still prevalent. We highlighted potential opportunities and threats within the current system, some of which were dependent upon larger political systems governing the NHS in the UK. Conclusion: The Foundation Programme is a robust approach to the training and development of early career doctors. Further research and a deeper international dialogue on the best-practice in this field is needed.
\end{abstract}

\section{Resumo}

Introdução: Depois de completar os cinco anos do curso de graduação em medicina, todos os médicos recém-formados no Reino Unido cursam o Foundation Programme, com duração de dois anos, que visa proporcionar-Ihes a experiência, supervisão e orientação necessárias para prepará-los para uma carreira clínica em medicina. Os médicos cursando o Foundation Programme são membros remunerados das equipes dos serviços e realizam várias rotações clínicas supervisionadas por médicos experientes, um processo que é regulado pelo UK Foundation Programme Office. Objetivo: Este trabalho visa fornecer uma análise reflexiva sobre o Foundation Programme para maior informar o público internacional. Métodos: Uma análise crítica e reflexiva utilizando a matriz DAF0 (Debilidades, Ameaças, Fortalezas e Oportunidades) realizada por dois jovens médicos cursando o Foundation Programme do Reino Unido. Resultados e Discussão: Trata-se de um programa bem estabelecido, que permite aos graduados obterem uma ampla gama de experiência clínica, como médicos remunerados, porém com variações consideráveis, tanto a nível individual como coletivo. Problemas persistentes para os jovens médicos incluem jornadas longas de trabalho e ainda um predomínio de burocracia excessiva. Oportunidades e ameaças potenciais foram destacadas dentro do sistema atual, algumas delas dependentes do macro contexto político que rege o NHS no Reino Unido. Conclusão: 0 Foundation Programme é uma robusta iniciativa para a formação e desenvolvimento de médicos em início de carreira. São necessárias maiores investigações e um diálogo internacional mais aprofundado sobre as melhores práticas nesta área.

\section{Resumen}

Introducción: Al finalizar el curso de pregrado de cinco años en medicina, los médicos recién titulados en el Reino Unido participarán del Foundation Programme, con duración de dos años, destinado a darles la experiencia, la supervisión y la orientación necesarias para prepararlos para una carrera clínica en la medicina. Los médicos que atienden el Foundation Programme son miembros pagos de los equipos del servicio y realizan diversas rotaciones clínicas supervisadas por médicos con experiencia, un proceso que está regulado por el UK Foundation Programme Office. Objetivo: Este estudio tiene como objetivo proporcionar un análisis reflexivo sobre el Foundation Programme para mejor informar al público internacional. Métodos: Análisis crítico y reflexivo usando la matriz DAFO (Debilidades, Amenazas, Fortalezas y Oportunidades) realizado por dos jóvenes médicos que atienden al Foundation Programme del Reino Unido. Resultados y Discusión: Se trata de un programa bien establecido que permite a los graduados obtener una amplia gama de experiencia clínica, como médicos remunerados pero con variaciones considerables, tanto al nivel individual como colectivo. Problemas persistentes para los médicos jóvenes incluyen largas horas de trabajo y aún el predominio de una burocracia excesiva. Potenciales oportunidades y amenazas se han destacado en el sistema actual, algunos de ellos dependientes del macro contexto político que rige el NHS en el Reino Unido. Conclusión: El Foundation Programme es una iniciativa robusta para la formación y desarrollo de los médicos en inicio de carrera. Se requiere una mayor investigación y un diálogo internacional más profundizado sobre las mejores prácticas en esta área.

Cite as: Lawrence DS, Williams CG. The UK Foundation Programme for newly qualified doctors: a

SWOT analysis. Rev Bras Med Fam Comunidade. 2014;9(30):72-6. Disponível em:

http://http://dx.doi.org/10.5712/rbmfc9(30)874

\section{Keywords:}

Health Human Resource

Training

Physicians, Junior

Education, Medical

Great Britain

Palavras-chave:

Capacitação de Recursos Humanos em Saúde Médicos Recém-Formados Educação Médica Reino Unido

Palabras clave: Capacitación de Recursos Humanos en Salud Médicos Recién Graduados Educación Médica Reino Unido

\section{Funding:} none declared.

Competing interests: none declared. 


\section{Introduction}

In the United Kingdom, medical graduates undertake a two year Foundation Programme (FP) which provides them with the necessary experience, supervision and guidance to prepare them for a career in clinical medicine. ${ }^{1}$

The FP is composed of Foundation Year 1 (F1) and Foundation Year 2 (F2). Each year is formed of three or four rotations around different departments of internal medicine, surgery, medical specialities and General Practice. Each doctor is supported by a Clinical Supervisor, typically their named Consultant who assists with clinical and professional development during each rotation, and they also have access to an Educational Supervisor throughout the entire programme to provide guidance and advice in areas related to clinical and personal affairs, if required.

There exists a Foundation Programme Curriculum which sets out the framework for educational progression and all Foundation Doctors must demonstrate competency in a broad range of areas including communication and consultation skills, patient safety and team work as well as the more traditional elements of medical training. ${ }^{2}$ In order to demonstrate a Foundation Doctor satisfies all the competences outlined in the Curriculum, an e-portfolio collates evidence provided over the course of the FP. ${ }^{3}$ A key component of this process is Supervised Learning Events involving in-depth discussion of cases and supervised examination of patients assessed by senior clinicians. Alongside this, Foundation Doctors record training courses, audit and research undertaken, as well as writing personal reflections on notable experiences during their clinical work.

F1 doctors hold a provisional registration with the General Medical Council (GMC) and must demonstrate they have met the core competences of the F1 Curriculum before progressing to F2. This forms the basis of the Annual Review of Competence Progression (ARCP) which, upon successful completion, enables a doctor to progress to F2 and also gain full registration with a licence to practice medicine with the GMC. ${ }^{4}$

Foundation Doctors are paid during this period: the basic F1 salary is $£ 22,636$ and for an F2 this increases to $£ 28,076$. $^{5}$ As most clinical jobs include on-call shifts and working during the night or over the weekend, they are often subjected to a supplement to the salary ranging from an additional 10\%-50\%, dependent on the number of anti-social hours worked. All rotations are planned to be compliant with the European Working Time Directive (EWTD) which stipulates that doctors should not work more than an average of 48 hours per working week. ${ }^{6}$

All of the above is facilitated by the UK Foundation Programme Office (FPO) who continue to develop the FP across the UK and are jointly funded by Health Education England and other NHS departments. The FPO coordinate the recruitment of all newly qualified doctors through a quantitative scoring system: all graduates receive a score out of 100 based on their relative success compared to their peers during their undergraduate degree combined with their performance in a national Situational Judgement Test (SJT) which assesses their ability to prioritise actions in given clinical and professional scenarios. Applicants prioritise the 21 Foundation Schools across the UK and places are allocated based on their scores.

One variation of the above model is the Academic Foundation Programme, an opportunity for early-career academics to develop their skills during the FP by undertaking one four month period of research in a designated field during the two-year programme. Academic Foundation Doctors must meet the standard requirements of the Foundation Curriculum but also those outlined in the Foundation Programme Academic Compendium during their FP. ${ }^{7}$

There exists significant variation between countries in terms of both the undergraduate and early career programmes. After a predominantly study-based first two years, UK graduates spend the final three years of their degree in the clinical environment, particularly in the final year, contributing to teams in the hospital setting, before completing the two year FP. Other countries integrate elements of the FP into the final two years of their undergraduate degree, with students immersing themselves in clinical work but with fewer responsibilities and no salary during this time. For example, Foundation Doctors can freely prescribe most medication and make the decision to admit or discharge patients in the acute setting. Given this variation between countries, and the fact that doctors in the UK start their life as a qualified doctor earlier, the objective of this paper was to provide a reflective analysis of the Foundation Programme to greater inform the international audience. 


\section{Methods}

The authors are both Foundation Doctors with the South Thames Foundation School, working at Brighton and Sussex University Hospitals NHS Trust. Dr Lawrence is an Academic F2 Doctor, and Dr Williams is an F1 Doctor. The authors undertook a critical reflective analysis of their personal experiences in the Foundation Programme using a Strength, Weaknesses, Opportunities and Threats (SWOT) Analysis format.

\section{Results and discussion}

\section{Strengths}

One of the key strengths of the FP is that doctors gain responsibility and experience caring for sick patients in busy hospitals across the UK. As a fully-fledged, paid member of the team, students become doctors and, with adequate supervision, are fully involved in admitting, treating, discharging and following up patients with a range of illnesses.

During the time as a medical student, future doctors can feel burdensome and are often forced to spend time seeking out the broadest range of presentations as possible, achieving sign-off of portfolios and juggling revision for regular examinations. As a full-time member of a team, a junior doctor feels more integrated into the medical profession and gains skills working as one part of a large multi-disciplinary team working together to improve the health of patients. This differs from some international contexts where, after the same number of years in training, people are still students and not practising doctors.

All Foundation Doctors undertake at least six different clinical rotations across different specialities of hospital medicine, with the option to opt into General Practice available to many. As doctors have a certain amount of choice over which rotations they undertake, they can gain a wide range of clinical exposure and this can inform decisions related to career choices for the future so that doctors rarely commence Speciality Training without having previous experience working in this field.

Clearly a huge benefit to the individual is a regular income. As medical school is a long, expensive process for many, finally being able to claim financial independence and start paying off the huge mounting debts relieves a great deal of pressure from the individual and enables them to focus solely on their work, as opposed to worrying about financial hardships or having to undertake a job outside of studying. This is not the case for everyone, as some still struggle with finances beyond graduation and others may have never had such concerns due to substantial parental contributions.

Finally, despite organisational fears over recent years that the number of doctors would exceed the number of Foundation posts available, this has not been the case and numbers have been well matched. ${ }^{8}$ This is a potential threat for the future.

\section{Weaknesses}

The FP is a large, ambitious operation which facilitates the training of all F1 and F2 doctors over the entire UK. Clearly, it would be unrealistic to expect that the FP provides the same experience for all those undertaking it. There is considerable variation between doctors in their overall experience: an annual survey of Foundation Doctors conducted by the GMC in 2013 found that the overall satisfaction with training was $77.7 \%(n=14,459)$, with teaching being excellent or good in just $56.5 \%$ of responses. ${ }^{9}$

Alongside this, even within one's FP, there can be huge variation in satisfaction between different rotations. In the GMC survey, there were considerable differences in satisfaction between specialities, with Anaesthetics providing the most satisfaction (90.8\% in F1 and $90.9 \%$ in F2) and Surgery the lowest (71.4\% in F1 and 72.7\% in F2). Clearly, personal preference and interest will have a strong impact upon satisfaction levels but this level of variation shows that some specialities are not providing a meaningful training experience for Foundation Doctors.

From our personal experience, satisfaction with a post is often strongly influenced by the level of clinical supervision and the support provided by senior members of the team. According to the same survey, only $77.6 \%$ of F1 doctors said they agreed that in their current post they had access to a senior colleague at all time. Overall, $12 \%$ of Foundation Doctors 
found it difficult to access their clinical supervisor and $9.4 \%$ said they were supervised by someone who they felt was not confident to do so: $1.5 \%$ on a daily basis, $3.3 \%$ on a weekly basis, and $4.6 \%$ on a monthly basis. One key concern of Foundation Doctors is of having to cope with clinical problems beyond their competence or experience, something $1.8 \%$ of respondents felt forced to cope with on a daily basis, $10.6 \%$ on a weekly basis and $15.9 \%$ on a monthly basis.

Foundation Doctors frequently possess an enthusiasm to immerse themselves in their new career, wanting to gain as much hands-on experience and competence in their field as possible. Unfortunately, a proportion of F1 and F2 jobs are supernumerary, whereby the doctor works a normal working week, typically in a very specialised area of medicine, such as Psychiatry or Intensive Care, and does not have the level of experience required to give a great input to the care of the patient. These are useful learning opportunities for those interested in the speciality, but doctors report feeling more like medical students helping out rather than giving meaningful contributions to patient care. A benefit to these is that doctors have a relatively low-stress job and more time to spend more time outside of the clinical environment.

One extremely time-consuming aspect of the FP is the e-portfolio where doctors keep a record of their achievements. A large number of assessments need to be completed to attain a positive ARCP outcome and these often depend on getting one-on-one time with supervisors to complete them. Alongside this, a significant amount of time is spent outside work completing the various components of the e-portfolio and preparing for the ARCP. This, on top of the large amount of paperwork that forms part of everyday work for the NHS, can be burdensome for juniors and is not always felt to be directly linked to their actual professional development. This is compounded by the complex interface and lack of user-friendliness of the online system. A counter-argument to this being that it enables doctors to build an evidence-base to their professional development.

One final weakness of the FP, and of working as a doctor in the NHS in general, is the extensive working hours. Despite claiming to be EWTD compliant, doctors are often expected to arrive to work earlier than their scheduled start time to prepare for the day and frequently work late, often without financial compensation. The GMC survey found that $69.9 \%$ of respondents said they worked beyond their rostered hours on a daily or weekly basis, with just $21.2 \%$ rarely or never working beyond these hours. Additionally, 32.1\% of foundation doctors said their working pattern left them feeling short of sleep when at work on a daily or weekly basis. Being overworked and overtired has historically been seen as a given aspect of a junior doctor's life, often romanticised by seniors as a rite of passage. Despite this, tired doctors who are over-worked are more likely to be demotivated and make mistakes. Our personal experience reflects this reality.

\section{Opportunities}

The key opportunity identified for the FP is the existing rigorous monitoring and evaluation process undertaken by the FPO and their partners, such as the GMC, which facilitates an open culture of feedback to improve its operations. With these mechanisms already well-established and stakeholders frequently held to account, it is foreseeable that continuous improvement of the FP can be possible, providing resources are available to do facilitate this. Similarly, there is eagerness to conduct research into the effectiveness of the system, focused on improving the experiences of doctors and patients.

Currently the Foundation e-portfolio does not link with similar systems used by doctors further along in their career. Another opportunity is to have a universal system which allows continuity throughout career progression and reduces the amount of replication between systems.

\section{Threats}

One key threat to the integrity of the FP is a potential mismatch between the number of graduates and the number of posts available. As more medical schools open, and existing universities increase the number of enrolled students, it is foreseeable that we shall have an excess of doctors in the UK. This will be compounded by the increasing number of British nationals who leave the UK to train abroad and return after their studies in search of a job.

The NHS is currently approaching a tipping point, with an ageing population with complex comorbidities, more services being privatised, and ongoing financial concerns. It is beyond the scope of this article to discuss the potential ramifications of these changes on the training experience of junior doctors, but an awareness of the political, social and economic determinants of health in the UK is a key priority for all staff.

In Table 1 we present a summary of the main points discussed in this paper. 
Table 1. A summary of the SWOT Analysis.

\begin{tabular}{ll}
\hline \multicolumn{1}{c}{ Strengths } & \multicolumn{1}{c}{ Weaknesses } \\
\hline Gain responsibilities early in career & Variable experience (group and individual) \\
Broad range of medical specialities & Supernumerary posts \\
Choice of medical specialities & E-portfolio \\
Salaried job & Long hours \\
Doctors and vacancies well matched & \multicolumn{1}{c}{ Opportunities } \\
\hline Mechanisms to facilitate improvement & Impending surplus of doctors \\
Linking e-portfolios with one another & Uncertainties regarding the future of the NHS \\
\hline
\end{tabular}

\section{Conclusions}

The above outlines the basic structure of the Foundation Programme as well as the perceived strengths, weaknesses, opportunities and threats based upon personal experience and feedback obtained from thousands of junior doctors. We demonstrate numerous strengths of a well-established system which enables graduates to gain a broad range of clinical experience under the supervision of senior clinicians in their role as fully salaried junior doctors. We describe key weaknesses of the system rooted in the variation of experience at the group and individual level and long-standing shortcomings of a junior doctor's career. Finally, we highlighted potential opportunities and threats within the current system, some of which are dependent upon larger political systems governing the NHS in the UK.

We acknowledge the limitations of this reflective review. This cannot be an exhaustive analysis and is based upon personal reflections of the authors who are both doctors are the same Foundation School. A lot of our observations are context specific and may not be a true representation of the greater population, something we try to ameliorate with the addition of population scale data. It is difficult to hypothesise whether a different system would induce similar criticisms, some of which are rooted more deeply in wider organisational issues within the NHS and medical training globally. Consequently, we advocate further research and a deeper international dialogue on the best-practice in this field.

\section{References}

1. Foundation Programme. [Internet]. UK: UKFPO; c2014 [cited 2014 Jan 17]. About the programme. Available from: http://www.foundationprogramme. nhs.uk/pages/home/about-the-foundation-programme

2. Foundation Programme. [Internet]. UK: UKFPO; c2014 [cited 2014 Jan 17]. The UK Foundation Programme Curriculum. The UK Foundation Programme Office. 2012. Available from: http://www.foundationprogramme.nhs.uk/pages/home/curriculum-and-assessment/curriculum2012

3. Foundation Programme. [Internet]. UK: UKFPO; c2014 [cited 2014 Jan 17]. E-portfolio. Available from: http://www.foundationprogramme.nhs.uk/ pages/foundation-doctors/e-portfolio

4. Foundation Programme. [Internet]. UK: UKFPO; c2014 [cited 2014 Jan 17]. Foundation ARCP. Available from: http://www.foundationprogramme. nhs.uk/pages/home/foundation-ARCP

5. NHS Careers. [Internet]. UK: NHS; c2006 [cited 2014 Jan 17]. Pay for doctors. Available from: http://www.nhscareers.nhs.uk/explore-by-career/ doctors/pay-for-doctors/

6. NHS Employers. [Internet]. UK: NHS; c2014 [cited 2014 Jan 17]. European Working Time Directive. Available from: http://www.nhsemployers.org/ PlanningYourWorkforce/MedicalWorkforce/EWTD/Pages/EWTD.aspx

7. Foundation Programme. [Internet]. The UK Foundation Programme: Academic Compendium. UK: UKFPO; 2013 Jul [cited 2014 Jan 17]. Available from: http://www.foundationprogramme.nhs.uk/download.asp?file=FINAL_C16029_UKFPO_ACADEMIC_COMPENDIUM_2013_PRINT.pdf

8. Jacques H. Foundation programme oversubscription is higher than in previous years. BMJ Careers. 2013 Jan 23. Available from: HYPERLINK "http://careers.bmj.com/careers/advice/view-article.html?id=20010564" http://careers.bmj.com/careers/advice/view-article.html?id=20010564\#

9. General Medical Council. National training survey 2013: foundation training. UK: General Medical Council; 2013 Dec. Available from: http://www. gmc-uk.org/NTS_2013_report__foundation_training.pdf_54580381.pdf 